\title{
Differentiation, Distribution, and Elimination of Two Different Pineapple mealybug wilt-associated viruses Found in Pineapple
}

\author{
D. M. Sether, Department of Plant and Environmental Protection Sciences, University of Hawaii at Manoa, Hono- \\ lulu 96822; A. V. Karasev, Department of Microbiology and Immunology, Thomas Jefferson University, Doyles- \\ town, PA 18901; C. Okumura, Department of Plant and Environmental Protection Sciences, University of Hawaii \\ at Manoa; C. Arakawa and F. Zee, USDA-ARS National Clonal Germplasm Repository, P.O. Box 4487, Hilo, HI \\ 96720; and M. M. Kislan, J. L. Busto, and J. S. Hu, Department of Plant and Environmental Protection Sciences, \\ University of Hawaii at Manoa
}

\begin{abstract}
Sether, D. M., Karasev, A. V., Okumura, C., Arakawa, C., Zee, F., Kislan, M. M., Busto, J. L., and Hu, J. S. 2001. Differentiation, distribution, and elimination of two different Pineapple mealybug wilt-associated viruses found in pineapple. Plant Dis. 85:856-864.

Surveys for Pineapple mealybug wilt-associated virus-1 (PMWaV-1) and PMWaV-2 were conducted on pineapple samples from Hawaii and around the world. Tissue blot immunoassays (TBIAs) with two different monoclonal antibodies (MAb) specific to either PMWaV-1 or PMWaV-2 indicated that both closteroviruses are widely distributed throughout the pineapplegrowing areas of the world. In the worldwide survey, PMWaV-1 was found in $80 \%$ of the mealybug wilt of pineapple (MWP)-symptomatic and $78 \%$ of the asymptomatic pineapple plants tested. A subset of plants was tested for PMWaV-2; 100\% of the symptomatic plants and $12 \%$ of the asymptomatic plants were positive for this virus. A reverse transcription-polymerase chain reaction (RT-PCR) assay was developed to differentiate between PMWaV-1 and PMWaV-2. Oligonucleotide primers were designed using distinct regions of the HSP 70 homolog genes of the two viruses. PMWaV-specific RT-PCR assays and TBIAs were used to screen the pineapple accessions maintained at the United States Department of Agriculture-Agricultural Research Service National Clonal Germplasm Repository for PMWaV infection; $73 \%$ of the accessions were found infected with at least one PMWaV. Pineapple accessions found PMWaV-free were challenged with viruliferous mealybugs to test for immunity to PMWaV-1. No immune germ plasm was identified. Potential alternative virus hosts were screened for infection with virusspecific RT-PCR assays and TBIAs and were also challenged with viruliferous mealybugs. No alternate hosts of PMWaV-1 or PMWaV-2 were identified. PMWaV-1 infection was eliminated through axillary and apical bud propagation from infected crowns. Strategies to manage MWP are discussed.
\end{abstract}

Additional keywords: closterovirus, Dysmicoccus spp., mealybug wilt of pineapple, MWP, PCV

Mealybug wilt of pineapple (MWP) is currently present in all the major pineapple-growing areas of the world (1,3$5,13,14,25,26)$. MWP is characterized by severe tip dieback, downward curling, reddening, and wilting of the leaves which can lead to total collapse of the plant (2). Historically, mealybug feeding on the

Corresponding author: J. S. Hu

E-mail: johnhu@hawaii.edu

This research was funded, in part, by grants from the State of Hawaii Governor's Agricultural Coordinating Committee contract No. 87-12 and the Hawaii Department of Agriculture contract No. 43754, and by the specific Cooperative Grant agreement 58-5320-5-604 between the USDAARS and the University of Hawaii. This is Journal Series No. 4551 of the College of Tropical Agriculture and Human Resources.

Accepted for publication 30 April 2001.

Publication no. D-2001-0618-01R

(C) 2001 The American Phytopathological Society pineapple plant has been associated with MWP symptoms $(2,6-8,15,19)$. In the last two decades, flexuous rod-shaped virus particles, designated Pineapple mealybug wilt-associated virus (PMWaV), have been isolated from both symptomatic and asymptomatic pineapple plants $(9,12,13,26)$. PMWaV is actually a complex of at least two different viruses, PMWaV-1 and PMWaV-2 (18) that are transmitted by mealybugs $(20,22)$. Based on particle morphology $(9,10)$ and genomic characteristics (18), it is suggested that PMWaV-1 and PMWaV-2 be placed in the family Closteroviridae and in the proposed genus, Vinivirus $(16,18)$. PMWaV-1 has previously been detected from both MWP symptomatic and asymptomatic pineapple plants in commercial Hawaiian pineapple fields and in the pineapple germ plasm collection at the United States Department of Agriculture-Agricultural Research Service (USDA-ARS) National Clonal Germplasm Repository (NCGR) in Hilo, HI $(12,13)$. Infection with PMWaV-1 is corre- lated with growth reductions in the plant crop (20) and yield reductions in the ratoon crop (23). We have recently shown that PMWaV-2 infection and mealybug feeding are necessary for the development of MWP in Hawaii $(11,21)$. The field distribution of PMWaV-2 in Hawaii and worldwide is unknown. In this article, we present survey data for incidence of PMWaV-1 and PMWaV-2 infections in worldwide and local proprietary selections, and introduce reverse transcription-polymerase chain reaction (RT-PCR) assays that detect and distinguish PMWaV-1 and PMWaV-2. We also present survey data for PMWaV-1 and PMWaV-2 incidence in the pineapple germ plasm maintained at the USDA-ARS NCGR and in weed, tree, and shrub species frequently found adjacent to MWP areas in commercial plantings. In addition, we test PMWaV-free germ plasm for PMWaV immunity using viruliferous mealybugs for virus transmission. Last, we demonstrate that PMWaV infection can be eliminated through axillary and apical bud tissue culture propagation from infected crowns.

\section{MATERIALS AND METHODS}

RT-PCR assay and Southern blotting. Pineapple plant leaf tissue $(100 \mathrm{mg})$ or mealybugs (approximately 50) were ground in liquid nitrogen and total RNA was extracted using RNeasy Plant Mini Kits (Qiagen Inc., Chatsworth, CA). Purified RNA samples were stored at $-80^{\circ} \mathrm{C}$ until used. First-strand cDNAs of portions of the PMWaV-1 and PMWaV-2 HSP 70 homolog genes were synthesized from 2.5 to $7 \mu \mathrm{g}$ of RNA using complementarystrand primers 223 and 226 for PMWaV-2 and PMWaV-1, respectively (Table 1). RT reactions $(20 \mu \mathrm{l})$ contained $3 \mu \mathrm{l}$ of RNA template, 0.75 pmols primer, $500 \mathrm{mM}$ dNTPs, $5 \mathrm{mM} \mathrm{MgCl}_{2}, 4 \mu \mathrm{l}$ of RT buffer (250 mM Tris-HCl, pH 8.3, 375 mM KC, $15 \mathrm{mM} \mathrm{MgCl}_{2}, 50 \mathrm{mM}$ DTT), 20 units of RNasin Ribonuclease Inhibitor (Promega, Madison, WI), and 65 units of MMLV reverse transcriptase (Promega). Firststrand synthesis was at $42^{\circ} \mathrm{C}$ (45 min) followed by inactivation at $95^{\circ} \mathrm{C}(5 \mathrm{~min})$. PCRs were carried out in the same tube using primers 224 and 225 for PMWaV-2 and PMWaV-1, respectively (Table 1). 
PCRs $(50 \mu \mathrm{l})$ consisted of 0.75 pmols of $3 \mu \mathrm{l}$ of reaction buffer $(500 \mathrm{mM} \mathrm{KCl}, 100$ $\mathrm{mM}$ Tris- $\mathrm{HCl}\left[\mathrm{pH} 9.0\right.$ at $\left.25^{\circ} \mathrm{C}\right], 1.0 \%$ [vol/vol] Triton X-100), and $0.5 \mu \mathrm{l}$ of Taq DNA polymerase (Promega). PCR conditions were initial denaturation at $94^{\circ} \mathrm{C}(4$ $\min )$, then 45 cycles of $94^{\circ} \mathrm{C}(1 \mathrm{~min}), 54^{\circ} \mathrm{C}$ (1 min), and $72^{\circ} \mathrm{C},(1 \mathrm{~min})$ followed by a sense- and complementary-strand primers,

final extension at $72^{\circ} \mathrm{C}(10 \mathrm{~min})$ in a Perkin Elmer 480 thermocycler. Amplicons were visualized in $1 \%$ agarose gels stained with ethidium bromide. Gels were denatured, neutralized, and transferred in $10 \times$ SSC (1× SSC is $0.15 \mathrm{M} \mathrm{NaCl}$ plus 0.015 $\mathrm{M}$ sodium citrate) overnight onto ZetaProbe GT membranes (BioRad, Hercules, CA) for Southern blot analysis. $\alpha$ -

Table 1. Primer sequences, amplicon product size, and nucleotide position in the HSP 70 homolog genes of Pineapple mealybug wilt-associated virus-1 (PMWaV-1) and PMWaV-2

\begin{tabular}{lclcc}
\hline PMWaV & Primer & \multicolumn{1}{c}{ Sequence } & Product size $^{\text {Nucleotide }}$ \\
\hline 1 & $225^{y}$ & 5'-ACAGGAAGGACAACACTCAC-3' & 589 & 118 \\
1 & $226^{z}$ & 5'-CGCACAAACTTCAAGCAATC-3' & $\ldots$ & 707 \\
2 & $224^{y}$ & 5'-CATACGAACTAGACTCATACG-3' & 609 & 226 \\
2 & $223^{z}$ & 5'-TCATTGCACTCACTTATCGTTG-3' $^{\prime}$ & $\ldots$ & 835 \\
\hline
\end{tabular}

${ }^{\mathrm{x}}$ Primer location (nucleotide position) from beginning of PMWaV HSP70 homolog gene.

${ }^{y}$ Sense-strand primer.

${ }^{\mathrm{z}}$ Complementary-strand primer.
${ }^{32}$ PdCTP-labeled probes were synthesized with a Random Primed DNA Labeling System (Life Technologies, Baltimore, MD) using clones 18 and 12 as templates. Clone 18 spanned nucleotides 25 to 983 and clone 12 spanned nucleotides 25 to 948 of the HSP 70 homolog genes of PMWaV1 and 2, respectively (18). Blots were hybridized overnight at $65^{\circ} \mathrm{C}$ and washed two times at low stringency $(20 \mathrm{mM}$ sodium phosphate, $\mathrm{pH} 7.2 ; 5 \%$ sodium dodecyl sulfate [SDS]) and two times at high stringency $(20 \mathrm{mM}$ sodium phosphate, $\mathrm{pH} 7.2$; $1 \% \mathrm{SDS}$ ) for $30 \mathrm{~min}$ each at $65^{\circ} \mathrm{C}$. Blots were exposed to Kodak X-OMAT film for 5 to $10 \mathrm{~min}$.

Monoclonal antibody detection of PMWaVs. Nitro ME membranes (Micron Separations, Inc., Westborough, MA) were placed over several layers of paper towels and sandwiched in cardboard cassettes designed to allow blotting of pineapple leaf

Table 2. Pineapple mealybug wilt-associated virus-1 (PMWaV-1) and PMWaV-2 infection status of pineapple from around the world

\begin{tabular}{|c|c|c|c|c|c|c|c|}
\hline \multirow[b]{2}{*}{ Source ${ }^{y}$} & \multirow[b]{2}{*}{ I.D. ${ }^{\mathrm{z}}$} & \multicolumn{2}{|c|}{ Symptomatic ${ }^{v}$} & \multicolumn{2}{|c|}{ Asymptomaticw $^{w}$} & \multicolumn{2}{|c|}{ Unknown $^{x}$} \\
\hline & & 1 & 2 & 1 & 2 & 1 & 2 \\
\hline Australia, Queensland & C-10 & $15 / 21$ & NT & $0 / 18$ & NT & $\ldots$ & $\ldots$ \\
\hline Australia, Queensland & F-180 & $10 / 10$ & NT & $13 / 13$ & NT & $\ldots$ & $\ldots$ \\
\hline Brazil & Perola & $1 / 6$ & $5 / 5$ & $\ldots$ & $\ldots$ & $\ldots$ & $\ldots$ \\
\hline Brazil & Smooth Cayenne & $6 / 15$ & $9 / 9$ & $\ldots$ & $\ldots$ & $\ldots$ & $\ldots$ \\
\hline China, Guangzhou & Cayenne & $\ldots$ & $\ldots$ & $\ldots$ & $\ldots$ & $9 / 54$ & $0 / 45$ \\
\hline Costa Rica & Champaka & $9 / 9$ & NT & $30 / 55$ & $6 / 25$ & $\ldots$ & $\ldots$ \\
\hline Costa Rica & Cayenne & $8 / 8$ & NT & $7 / 7$ & NT & $\ldots$ & $\ldots$ \\
\hline Costa Rica & $\mathrm{CO}-2$ & $\ldots$ & $\ldots$ & $1 / 17$ & $0 / 16$ & $\ldots$ & $\ldots$ \\
\hline Costa Rica & Manzana & $\ldots$ & $\ldots$ & $7 / 7$ & NT & $\ldots$ & $\ldots$ \\
\hline Costa Rica & Mayan Gold 3 & $\ldots$ & $\ldots$ & $3 / 33$ & $0 / 30$ & $\ldots$ & $\ldots$ \\
\hline Costa Rica & Mayan Gold 4 & $\ldots$ & $\ldots$ & $3 / 25$ & $0 / 22$ & $\ldots$ & $\ldots$ \\
\hline Costa Rica & Monte Lirio & $\ldots$ & $\ldots$ & $11 / 12$ & $0 / 1$ & $\ldots$ & $\ldots$ \\
\hline Costa Rica & MacGregor (Queen) & $\ldots$ & $\ldots$ & $7 / 8$ & $0 / 1$ & $\ldots$ & $\ldots$ \\
\hline France, Martinique & Cayenne & $\ldots$ & $\ldots$ & $\ldots$ & $\ldots$ & $32 / 66$ & $7 / 34$ \\
\hline France, Martinique & N.A. & $\ldots$ & $\ldots$ & $\ldots$ & $\ldots$ & $10 / 61$ & $1 / 51$ \\
\hline Guyana, Demerara & Monserrat & $52 / 52$ & NT & $61 / 61$ & $\mathrm{NT}$ & $\ldots$ & $\ldots$ \\
\hline Honduras & F-153 & $20 / 20$ & NT & $15 / 19$ & $0 / 4$ & $\ldots$ & $\ldots$ \\
\hline Honduras & Ghanas & $\ldots$ & $\ldots$ & $10 / 10$ & NT & $\ldots$ & $\ldots$ \\
\hline Honduras & Ivory Coast & $\ldots$ & $\ldots$ & $3 / 10$ & $7 / 7$ & $\ldots$ & $\ldots$ \\
\hline Honduras & Mayan Gold 1 & $\ldots$ & $\ldots$ & $59 / 60$ & $0 / 1$ & $\ldots$ & $\ldots$ \\
\hline Honduras & Mayan Gold 2 & $\ldots$ & $\ldots$ & $20 / 28$ & $0 / 8$ & $\ldots$ & $\ldots$ \\
\hline Honduras & Mayan Gold 3 & $\ldots$ & $\ldots$ & $1 / 10$ & $0 / 9$ & $\ldots$ & $\ldots$ \\
\hline Honduras & Honduran Field Run & $\ldots$ & $\ldots$ & $5 / 5$ & NT & $\ldots$ & $\ldots$ \\
\hline Honduras, La Ceiba & N.A. & $60 / 65$ & $5 / 5$ & $44 / 47$ & $0 / 3$ & $\ldots$ & $\ldots$ \\
\hline Honduras & N.A. & $101 / 105$ & $4 / 4$ & $103 / 111$ & $2 / 8$ & $\ldots$ & $\ldots$ \\
\hline India & Pundlur & $23 / 23$ & NT & $\ldots$ & $\ldots$ & $\ldots$ & $\ldots$ \\
\hline India & Tiptur & $31 / 31$ & NT & $\ldots$ & $\ldots$ & $\ldots$ & $\ldots$ \\
\hline Indonesia, Jakarta & Smooth Cayenne & $58 / 62$ & $4 / 4$ & $53 / 57$ & $4 / 4$ & $\ldots$ & $\ldots$ \\
\hline Kenya, Thika & Smooth Cayenne & $60 / 64$ & $4 / 4$ & $18 / 18$ & NT & $\ldots$ & $\ldots$ \\
\hline $\begin{array}{l}\text { Malaysia, Pontian, } \\
\text { Johor }\end{array}$ & Gandul & $0 / 95$ & $95 / 95$ & $\ldots$ & $\ldots$ & $\cdots$ & $\ldots$ \\
\hline $\begin{array}{l}\text { Malaysia, Pontian, } \\
\text { Johor }\end{array}$ & Mauritius (Queen) & $0 / 5$ & $5 / 5$ & $\ldots$ & $\cdots$ & $\cdots$ & $\cdots$ \\
\hline Philippines, Makati City & Smooth Cayenne & $98 / 101$ & $3 / 3$ & $98 / 98$ & NT & $\ldots$ & $\ldots$ \\
\hline Philippines, Mindanao & F-200 & $2 / 2$ & $\ldots$ & $2 / 2$ & $\ldots$ & $\ldots$ & $\ldots$ \\
\hline Puerto Rico & N.A. & $\ldots$ & $50 / 50$ & $\ldots$ & $\ldots$ & NT & $100 / 100$ \\
\hline South America & N.A. & $\ldots$ & $\ldots$ & $\ldots$ & $\ldots$ & $144 / 144$ & NT \\
\hline Sri Lanka, Columbo & Mauritius & $\ldots$ & $\ldots$ & $\ldots$ & $\ldots$ & $52 / 56$ & $4 / 4$ \\
\hline Thailand & Smooth Cayenne & $\ldots$ & $\ldots$ & $22 / 35$ & $0 / 13$ & $\ldots$ & $\ldots$ \\
\hline Vietnam & Queen & $\cdots$ & $\cdots$ & $\ldots$ & $\ldots$ & $93 / 93$ & NT \\
\hline
\end{tabular}


samples onto the membrane while providing rigidity to protect the membrane from breakage. The membranes in the cassettes with illustrated sampling instructions were mailed to pineapple growers and researchers around the world. Participants were asked to make transverse cuts through the basal white portion of pineapple leaves and to press the cut edge onto the membranes. Sample information, such as MWP symptoms, location and age of plant, and variety or cultivar, was also requested. Membranes were returned and processed first with monoclonal antibody (MAb) 35-6-5 for PMWaV-1 (13) and then with MAb 63-2-2 for PMWaV-2 (D. M. Sether and J. S. Hu, unpublished data) in tissue blot immunoassay (TBIA) as previously described (12).

Screening of Hawaiian selections and USDA-ARS NCGR accessions. Plants from one Ananas comosus clonal selection, five A. comosus 'Smooth Cayenne' clonal selections, and four hybrids from Hawaiian plantations were screened for PMWaV-1 and PMWaV-2 infection. Due to the proprietary nature of this material from Del Monte Fresh Produce (Hawaii), Inc., Dole Fresh Fruit Co., and Maui Pineapple Co, clonal selections and hybrids are identified only by numbers, as previously described (12). For each proprietary selection or hybrid, approximately equal numbers of leaf samples were sampled from each field and at least four healthy or MWP-symptomatic fields were sampled for each selection. Asymptomatic plants immediately adjacent in the row to MWP-symptomatic plants were sampled from selection 2. Leaf material was screened in parallel tests for PMWaV-1 and PMWaV-2 with specific MAbs in TBIAs. Infection rates were sub- jected to Wilcoxon rank sum test. Pineapple accessions maintained at the USDAARS NCGR in Hilo, HI, were screened for PMWaV-1 and PMWaV-2 with virus-specific RT-PCR assays and TBIAs as described.

Screening for alternate PMWaV hosts and immune germ plasm. Plants commonly found bordering pineapple fields in Hawaii or that are hosts of mealybugs (Dysmicoccus brevipes and D. neobrevipes) were established in the greenhouse. Plants (2 to 5 plants of each species) were inoculated with PMWaV-viruliferous mealybugs (D. brevipes and $D$. neobrevipes) as previously described (24). Pineapple plants representing PMWaV-free accessions from the USDA-ARS NCGR were also challenged with viruliferous mealybugs. PMWaV-free 'Smooth Cayenne' pineapple plants were included as PMWaV transmission controls. At 4 to 6 weeks after exposure to viruliferous mealybugs, leaves and roots of test plants were assayed by PMWaV-specific RT-PCRs, TBIAs, or both. Two to six plants from woody plant species frequently found growing adjacent to MWP-symptomatic areas of pineapple fields in Hawaii were also sampled. Leaf and petiole material from these plants was tested for PMWaVs with RT-PCR and TBIA.

PMWaV-1 elimination. PMWaV-1-infected pineapple crowns were given two heat treatments consisting of $35^{\circ} \mathrm{C}$ for $24 \mathrm{~h}$ followed immediately by either $58^{\circ} \mathrm{C}$ for $40 \mathrm{~min}$ or $56^{\circ} \mathrm{C}$ for $60 \mathrm{~min}$ in a water bath. Leaves were stripped from the crowns $24 \mathrm{~h}$ after the second heat treatment. PMWaV-1infected crowns that received no heat treatment were included as controls. Axillary

Table 3. Detection of Pineapple mealybug wilt associated virus (PMWaV)-1 and PMWaV-2 in Ananas comosus proprietary selections and hybrids grown in Hawaii

\begin{tabular}{|c|c|c|c|c|}
\hline \multirow[b]{2}{*}{ Description } & \multirow[b]{2}{*}{ Total samples $^{\mathbf{y}}$} & \multicolumn{3}{|c|}{ Percentage of total plants infected ${ }^{x}$} \\
\hline & & PMWaV-1 only & PMWaV-2 only & PMWaV-1 and -2 \\
\hline \multicolumn{5}{|l|}{ Asymptomatic } \\
\hline Hybrid 4 & 558 & $10 \mathrm{~g}$ & $3 \mathrm{hi}$ & $3 \mathrm{hi}$ \\
\hline Hybrid 5 & 453 & $10 \mathrm{~g}$ & $3 \mathrm{hi}$ & $5 \mathrm{~g}$ \\
\hline Hybrid 6 & 666 & $16 \mathrm{fg}$ & $12 \mathrm{fg}$ & $53 \mathrm{c}$ \\
\hline Hybrid 7 & 40 & $0 \mathrm{i}$ & $0 \mathrm{i}$ & $0 \mathrm{i}$ \\
\hline Selection 1 & 505 & $28 \mathrm{de}$ & $1 \mathrm{hi}$ & $0 \mathrm{i}$ \\
\hline Selection 2 & 920 & $26 \mathrm{e}$ & 20 ef & $8 \mathrm{~g}$ \\
\hline Selection 3 & 505 & $45 \mathrm{c}$ & $2 \mathrm{hi}$ & $2 \mathrm{hi}$ \\
\hline Selection 4 & 505 & $82 \mathrm{~b}$ & $1 \mathrm{hi}$ & 2 hi \\
\hline Selection 5 & 519 & $99 \mathrm{a}$ & $0 \mathrm{i}$ & $<1 \mathrm{i}$ \\
\hline Selection 6 & 564 & $34 \mathrm{de}$ & $<1 \mathrm{i}$ & $36 \mathrm{~cd}$ \\
\hline \multicolumn{5}{|c|}{ MWP symptomatic } \\
\hline Selection 2 & 385 & $0 \mathrm{i}$ & $0 \mathrm{i}$ & $100 \mathrm{a}$ \\
\hline Selection 5 & 502 & $0 \mathrm{i}$ & $0 \mathrm{i}$ & $100 \mathrm{a}$ \\
\hline Selection 6 & 408 & $0 \mathrm{i}$ & $2 \mathrm{hi}$ & $99 \mathrm{a}$ \\
\hline \multicolumn{5}{|c|}{ Immediately adj. ${ }^{\mathrm{z}}$} \\
\hline Selection 6 & 760 & $0 \mathrm{i}$ & $0 \mathrm{i}$ & $92 \mathrm{~h}$ \\
\hline
\end{tabular}

${ }^{x}$ PMWaV-1 and PMWaV-2 status was determined by PMWaV-specific tissue blot immunoassays; numbers followed by different letters are significantly different at $P<0.05$ based on Wilcoxon ranked sum test.

y Approximately equal samples were collected from a minimum of four different areas per selection with the exception of Hybrid 4, of which only greenhouse-grown material was sampled.

${ }^{\mathrm{z}}$ Plants growing in the same row immediately adjacent to mealybug wilt of pineapple-symptomatic plants. and apical buds were excised and surface sterilized in two washes with 15 and $10 \%$ bleach and 2 drops of Tween-20 per liter. Axillary buds were trimmed to $1-\mathrm{mm}$ square blocks while in a $5 \%$ bleach solution with Tween-20. These pieces were rinsed in distilled water and placed in media W (Murashige and Skoog Basal Salts [MS salts], with $\mathrm{N}^{6}$-benzyladenine [BA] at $2 \mathrm{mg} / \mathrm{liter}$, naphthalene acetic acid [NAA] at $2 \mathrm{mg} / \mathrm{liter}$, and agar at $9 \mathrm{~g} / \mathrm{liter}$ ). Buds were transferred twice at 21-day intervals, then placed in B2 media (0.5× MS salts, organic constituents [glycine at 2.0 $\mathrm{mg} / \mathrm{liter}$, nicotinic acid at $0.5 \mathrm{mg} / \mathrm{liter}$, pyridoxine $\mathrm{HCl}$ at $0.5 \mathrm{mg} / \mathrm{liter}$, thiamine $\mathrm{HCl}$ at $0.1 \mathrm{mg} / \mathrm{liter}$, thiamine $\mathrm{HCl}$ at 0.4 $\mathrm{mg}$ /liter, myo-inositol at $100 \mathrm{mg} / \mathrm{liter}, \mathrm{BA}$ at $1 \mathrm{mg} / \mathrm{liter}$, and sucrose at $30 \mathrm{~g} / \mathrm{liter}$ ). Once green leaves appeared, plantlets were transferred to Y2 media (0.5× MS salts, organic constituents, thiamine $\mathrm{HCl}$ at 0.4 $\mathrm{mg} /$ liter, myo-inositol at $100 \mathrm{mg} / \mathrm{liter}$, sucrose at $30 \mathrm{~g} / \mathrm{liter}$, and DifcoBacto agar at $9 \mathrm{~g} /$ liter) for rooting and then transplanted to soil. Cultures were grown under a daily cycle of $16 \mathrm{~h}$ of light and $8 \mathrm{~h}$ of dark at $25^{\circ} \mathrm{C}$. PMWaV-specific RT-PCR assays were performed prior to transplanting to soil. PMWaV-specific TBIAs were used 1 to 2 months after plants were established in soil.

\section{RESULTS}

Worldwide and local surveys. PMWaV-1 and PMWaV-2 were detected in pineapple leaves from around the world with PMWaV-specific TBIAs (Table 2). Both viruses were detected in MWP-symptomatic and asymptomatic plants. All samples from plants described as symptomatic from Costa Rica, Guyana, and India, $A$. comosus F180s from Australia, and $A$. comosus 'Champaka' F153s from Honduras were infected with PMWaV-1. PMWaV-1 was not detected in any symptomatic plants from Malaysia (0 of 100) and was only detected in $33 \%$ of the samples from Brazil (Table 2). Specific antibodies for PMWaV-2 were not available during initial screening of the blotted samples from the worldwide survey. When the MAbs for PMWaV-2 became available, the blots that were previously found to be negative with PMWaV-1 antibodies were reprobed with PMWaV-2-specific antibodies in TBIAs. PMWaV-2 was detected in $100 \%$ of the samples from MWP-symptomatic plants that were not already found infected with PMWaV-1. PMWaV-2 was also found in 19 of 44 samples (43\%) from asymptomatic PMWaV-1-free plants (Table 2).

Surveys of Hawaiian plantations showed a $100 \%$ correlation of MWP symptoms with the presence of PMWaV-2 (Table 3) but not with PMWaV-1. Plants growing immediately adjacent to MWP-symptomatic plants in the same row exhibited much higher rates of PMWaV-1 and 
PMWaV-2 infection than did asymptomatic plants from MWP-free areas of the same field (Table 3). Rates of PMWaV-2 infection in healthy-looking plants of Hawaiiangrown proprietary selections were generally much lower than PMWaV-1 infection rates (Table 3). Comparisons of mean infection rates among crowns collected from seven plant crops and two ratoon crops showed a substantial decrease in PMWaV infection rates in the ratoon crops (Fig. 1). PMWaV-1 and PMWaV-2 were both found in the pineapple accessions maintained at the USDA-ARS NCGR (Table 4). PMWaV-1, PMWaV-2, or mixed infections of both PMWaVs were found in 33, 9, and $40 \%$ of the accessions, respectively.

RT-PCR assays. RT-PCR amplicons of 589 bp were produced by primer set 225/226 (Table 1), specific for PMWaV-1 (Fig. 2), when used with RNA extracts from PMWaV-1-infected plants and PMWaV-1 and PMWaV-2 dually infected plants. Amplicons were not present in samples from plants that tested negative for PMWaV-1 with PMWaV-1-specific TBIA or in PMWaV-1-free plants that tested positive for PMWaV-2. Mealybugs reared on squash also tested negative with RT-PCR. RT-PCR amplicons of 609 bp were produced by primer set 224/223 (Table 1), specific for PMWaV-2 (Fig. 2), when used with RNA extracts from PMWaV-2-infected plants, PMWaV-1 and PMWaV-2 dually infected plants, and mealybugs from PMWaV-2-infected plants. Amplicons were not present in samples from plants that tested negative for PMWaV-2 with PMWaV-2-specific TBIA, PMWaV-2-free plants that tested positive for PMWaV-1, or mealybugs reared on squash. Southern blot analyses with ${ }^{32} \mathrm{P}$ labeled clones 18 and 12, which encompass the $5^{\prime}$-ends of the HSP 70 homolog genes from PMWaV-1 and -2, respectively, showed high homology with the 589-bp (PMWaV-1) or 609-bp (PMWaV-2) amplicons, respectively (Fig. 2). PMWaVspecific RT-PCR could detect virus in the floral bracts of infected plants as well as leaves from the crown or parent plant, whereas PMWaV-specific TBIA could not reliably detect virus in the floral bracts.

Potential alternate hosts and tests for immunity. No PMWaV infections were detected in field-collected samples from herbaceous weeds, shrubs, or trees growing adjacent to MWP-symptomatic pineapple fields (Table 5). Also, no PMWaV infections were detected after exposure to PMWaV-viruliferous mealybugs in agave, banana, cassia, chenopodium, grasses, or tobacco, whereas A. comosus Smooth Cayenne controls were infected by PMWaV readily. Several plants commonly found in pineapple fields were found to be hosts of Dysmicoccus sp. mealybugs (Table 5). No PMWaV-1-immune germ plasm was identified in the accessions maintained at the USDA-ARS NCGR. All pineapple plants were eventually infected with PMWaV-1, although A. bracteatus and Pseudoananas sagenarius plants required several applications of viruliferous mealybugs before virus could be detected.

Elimination of PMWaV-1 infection. PMWaV-1 infection was eliminated through apical and axillary bud propagation in $92 \%$ of the plants recovered in all treatments (Table 6). Size of crowns showed no differences in percentage of PMWaV-1-free plants recovered. Heat treatments to the crowns prior to bud excision did not improve recovery of PMWaV1-free plants. Plants that initially tested PMWaV-free with RT-PCR and TBIA assays after virus elimination were grown in soil for over 12 months and remained PMWaV-free based on PMWaV-specific TBIA and RT-PCR assays.

\section{DISCUSSION}

PMWaV-1- and PMWaV-2-specific TBIA assays showed that the two closteroviruses are distributed worldwide in both MWP-symptomatic and asymptomatic pineapple. This may indicate inadvertent transportation of systemically infected pineapple propagation material among countries. PMWaV-1 and PMWaV-2 were also found in the pineapple accessions maintained at the USDA-ARS NCGR in Hilo, on the island of Hawaii, and in the Hawaiian proprietary selections and hybrids grown on the islands of Maui and Oahu, where most of Hawaii's pineapple production occurs. In our study with selection number 6, significantly higher PMWaV infection rates were observed in plants immediately adjacent to MWPsymptomatic plants than in plants from healthy-appearing areas within the same field. This indicates that $\mathrm{PMWaVs}$ are acquired and transmitted in the field by their mealybug vectors. Mealybugs were always found in areas with MWP.

Only asymptomatic plants of the proprietary hybrids and three of the selections were available for testing at the time of this study. The hybrids are relatively new and have not yet been extensively cultivated; thus, these hybrids have not had the decades of mealybug exposure in the field that the other cultivated selections have had. We are currently testing the hybrids for susceptibility to MWP when exposed to both mealybugs and infected with PMWaV-2. The absence of PMWaV-1 and PMWaV-2 infection in hybrid 7 is likely due to the small number of samples tested and the absence of exposure to viruliferous mealybugs under field conditions. We have been able to infect plants from hybrid 7 with PMWaV-2 using viruliferous mealybugs (D. M. Sether and J. S. Hu, unpublished data). MWP has previously been observed in the proprietary selections 1,3 , and 4 (12). In a separate study, MWPsymptomatic plants from these three selections were found to be infected with
PMWaV-2 (D. M. Sether and J. S. Hu, unpublished data).

RT-PCR assays, confirmed by Southern analyses, were developed to detect and distinguish PMWaV-1 and PMWaV-2 infections. These assays provided a sensitive alternative to immunosorbent electron microscopy for confirming TBIA results. PMWaV-specific RT-PCR assays could detect PMWaV infections in floral bracts, which typically are not good sampling sources for TBIA assays. PMWaV-2 was detected in $100 \%$ of the MWP-symptomatic plants in the Hawaiian proprietary selections and in $100 \%$ of the MWP-symptomatic plants from around the world that were found to be PMWaV-1 negative. Previously, we found that MWP does not occur without the presence of both PMWaV-2 and mealybug feeding (D. M. Sether and J. $\mathrm{S}$. $\mathrm{Hu}$, unpublished data). PMWaV-1 and mealybug feeding does not result in MWP, nor does infection with PMWaV-2 in the absence of mealybug exposure (D. M. Sether and J. S. Hu, unpublished data). The correlation of PMWaV-2 infection and MWP in both the Hawaiian and worldwide surveys supports our earlier findings that PMWaV-2 infection is an integral part of MWP etiology.

To date, pineapple of Ananas and Pseudoananus spp. are the only known plant hosts of PMWaV-1 and PMWaV-2. No alternate PMWaV hosts were identified, although several species in the Poaceae and Liliaceae families that occur in the borders around pineapple fields were identified as mealybug hosts and were eliminated as sources of PMWaV which could be transmitted to the pineapple crops. The most common weeds were screened for PMWaVs with TBIA and RT-PCR assays and were also challenged with PMWaVviruliferous mealybugs. We suggest that MWP outbreaks observed on plantations are likely the result of initially nonviruliferous mealybugs, introduced from adjacent alternate mealybug hosts, becoming established on existing PMWaV-2infected plants. These plants may subsequently develop MWP. Secondary spread of PMWaV then occurs as mealybugs move from infected plants to PMWaV-free plants. Our serological and RT-PCR assays showed that PMWaV infection rates were

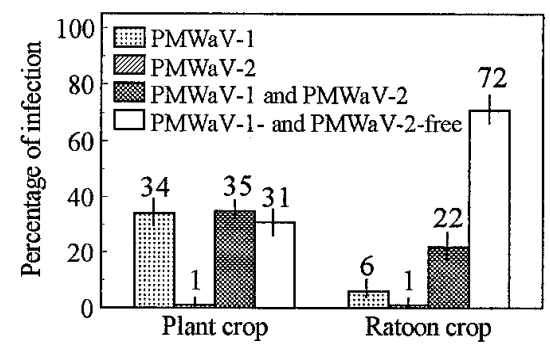

Fig. 1. Pineapple mealybug wilt-associated virus-1 (PMWaV-1) and PMWaV-2 infection rates in plant and ratoon crop cycles. 
Table 4. Pineapple mealybug wilt-associated virus (PMWaV) infection status of pineapple accessions maintained at the United States Department of Agriculture-Agricultural Research Service (USDA-ARS) National Clonal Germplasm Repository in Hilo, HI

\begin{tabular}{|c|c|c|c|c|c|c|}
\hline \multirow[b]{2}{*}{ No. ${ }^{q}$} & \multirow[b]{2}{*}{ Name $^{r}$} & \multirow[b]{2}{*}{ Geographic origin } & \multicolumn{2}{|c|}{ PMWaV-1 $^{\circ}$} & \multicolumn{2}{|c|}{ PMWaV-2p } \\
\hline & & & RT-PCR & TBIA & RT-PCR & TBIA \\
\hline 2 & $59-656$ & USA & $\ldots$ & + & $\ldots$ & - \\
\hline 3 & $61-2223$ & USA & $\ldots$ & + & $\ldots$ & - \\
\hline 4 & $58-1184$ & USA & $\ldots$ & + & $\ldots$ & - \\
\hline 6 & Tainung \#9 & Taiwan & $\ldots$ & + & + & + \\
\hline 7 & Cayenne lot $520 \mathrm{WBC}$ & USA & $\ldots$ & + & + & + \\
\hline 8 & Cayenne Lanai & USA & $\ldots$ & + & - & - \\
\hline 9 & Cayenne M263 & USA & $\ldots$ & + & + & + \\
\hline 10 & Cayenne Hilo & USA & $\ldots$ & + & + & - \\
\hline 11 & Columbia variety \#1 & USA & + & + & - & - \\
\hline 12 & 'Congo' & USA & $\ldots$ & $\ldots$ & + & + \\
\hline 13 & 'Spanish Samoa' & American Samoa & + & + & + & + \\
\hline 14 & 'Pernambuco' & Singapore & + & + & + & + \\
\hline 15 & 'Ruby' & Singapore & $\ldots$ & + & + & + \\
\hline 16 & 'Bermuda' & Barbados & $\ldots$ & - & + & - \\
\hline 17 & 'Natal' & S. Africa & + & + & + & + \\
\hline 18 & 'Mauritius' & Taiwan & + & + & + & + \\
\hline 20 & $\mathrm{~F} 101^{\mathrm{s}}$ & Brazil & $\ldots$ & + & + & + \\
\hline 21 & 'Abacaxi' & Brazil & $\ldots$ & + & + & + \\
\hline 23 & 'Sam Clarke' & Jamaica & + & + & - & $\ldots$ \\
\hline 24 & 'Monserrat' & Philippines & $\ldots$ & + & $\ldots$ & - \\
\hline 25 & 'Macgregor' & Philippines & $\cdots$ & - & $\cdots$ & + \\
\hline 27 & Wild Kailua, F 148 & USA & $\ldots$ & + & $\ldots$ & + \\
\hline 28 & 'Dacca' & Philippines & + & + & + & + \\
\hline 29 & 'Sugarloaf' & Philippines & $\ldots$ & + & $\ldots$ & - \\
\hline 30 & 'Sylhet Jaldubi' & Philippines & - & - & - & - \\
\hline 31 & 'Black Antigua' & Philippines & $\ldots$ & + & $\ldots$ & + \\
\hline 32 & 'Cambray' & Philippines & $\ldots$ & + & $\ldots$ & + \\
\hline 33 & 'Ananas Kendal' & Indonesia & + & + & - & + \\
\hline 34 & 'Monte Lirio' & Guatemala & $\ldots$ & + & $\ldots$ & + \\
\hline 35 & 'Amalsad' & India & + & + & - & - \\
\hline 37 & 'Criolla' & Mexico & $\ldots$ & + & $\ldots$ & + \\
\hline 38 & Wild Brazil, F $198^{t}$ & Brazil & - & - & - & - \\
\hline 39 & Philippine. Hyb. F 203" & Philippines & $\ldots$ & + & $\ldots$ & - \\
\hline 40 & 'Phu Qui' & Vietnam & $\ldots$ & + & $\ldots$ & + \\
\hline 41 & 'Pho Lang Tuang' & Vietnam & + & + & + & + \\
\hline 42 & 'Saigon Red' & Vietnam & $\ldots$ & + & $\ldots$ & + \\
\hline 43 & 'Mo’' & Vietnam & $\ldots$ & - & $\ldots$ & + \\
\hline 44 & 'Moe' & Vietnam & $\ldots$ & + & $\ldots$ & - \\
\hline 45 & 'NEP' & Vietnam & - & + & - & - \\
\hline 46 & 'Sugarloaf' & Zaire & - & + & + & + \\
\hline 47 & 'Canterra' & Columbia & $\ldots$ & + & $\ldots$ & + \\
\hline 49 & 'Pina Criolla' & Columbia & - & - & + & + \\
\hline 50 & 'Bogota' & Columbia & - & - & - & - \\
\hline 51 & 'Ananas De Vaupes' & Columbia & + & + & + & + \\
\hline 52 & 'Papuri Vaupes Columbia' & Columbia & $\ldots$ & + & $\ldots$ & - \\
\hline 53 & British Samoa P1 & Samoa & $\ldots$ & + & $\ldots$ & + \\
\hline 54 & British Samoa P5, F243 & Samoa & $\ldots$ & + & $\ldots$ & - \\
\hline 55 & 'Apaporis' & Columbia & $\ldots$ & + & $\ldots$ & - \\
\hline 56 & 'Apaporis P1' & Columbia & $\cdots$ & + & $\cdots$ & - \\
\hline 58 & Wild Brazil $\times$ Lot $520^{u}$ & USA & $\ldots$ & - & $\ldots$ & - \\
\hline 59 & F1 Cayenne $\times P$. sagenarius $^{\mathrm{u}}$ & USA & - & - & - & - \\
\hline 60 & 'Spanish Guatemala' & Guatemala & $\ldots$ & + & $\ldots$ & - \\
\hline 62 & 'Rio Kananari' & Columbia & + & + & - & - \\
\hline 63 & CB 2, Curawa ${ }^{v}$ & Brazil & - & - & - & - \\
\hline 64 & $\mathrm{CB} 5^{\mathrm{s}}$ & Brazil & $\ldots$ & + & $\ldots$ & - \\
\hline 65 & $\mathrm{CB} 6^{\mathrm{t}}$ & Brazil & - & - & - & - \\
\hline 66 & $\mathrm{CB} 9^{\mathrm{v}}$ & Brazil & + & + & - & - \\
\hline \multirow[t]{2}{*}{67} & $\mathrm{CB} 10^{\mathrm{t}}$ & Brazil & $\ldots$ & + & $\ldots$ & + \\
\hline & & & & & \multicolumn{2}{|c|}{ (continued on next page } \\
\hline
\end{tabular}

${ }^{\circ}$ PMWaV-1 was detected with PMWaV-1-specific primers in reverse transcription-polymerase chain reaction (RT-PCR) and PMWaV-1-specific MAb 356-5 in tissue blot immunoassay (TBIA).

p PMWaV-2 was detected with PMWaV-2-specific primers in RT-PCR and PMWaV-2-specific MAb 63-2-2 in TBIA.

q USDA-ARS National Clonal Germplasm Repository accession number.

${ }^{r}$ Varietal, cultivar, or other identifying name; all are Ananas comosus unless footnoted.

s A. bracteatus.

${ }^{\mathrm{t}}$ A. ananassoides.

u Ananus sp.

${ }^{\vee}$ A. erectifolius.

${ }^{\mathrm{w}}$ A. bracteatus var. rudis.

${ }^{\mathrm{x}}$ A. bracteatus var. tricolor.

${ }^{\mathrm{y}}$ A. nanus.

${ }^{\mathrm{z}}$ A. bracteatus var. albus. 
Table 4. (continued from preceding page)

\begin{tabular}{|c|c|c|c|c|c|c|}
\hline \multirow[b]{2}{*}{ No.q } & \multirow[b]{2}{*}{ Name $^{r}$} & \multirow[b]{2}{*}{ Geographic origin } & \multicolumn{2}{|c|}{ PMWaV-1 $^{\circ}$} & \multicolumn{2}{|c|}{ PMWaV-2p } \\
\hline & & & RT-PCR & TBIA & RT-PCR & TBIA \\
\hline 68 & $\mathrm{CB} 11^{\mathrm{s}}$ & Brazil & - & - & - & - \\
\hline 69 & CB $15^{\mathrm{t}}$ & Paraguay & + & + & + & + \\
\hline 70 & $\mathrm{CB} 17^{\mathrm{w}}$ & Paraguay & - & - & - & - \\
\hline 72 & CB $19^{t}$ & Paraguay & - & - & - & - \\
\hline 73 & CB $20^{\mathrm{w}}$ & Paraguay & - & - & - & - \\
\hline 74 & $\mathrm{CB} 21^{\mathrm{x}}$ & Paraguay & - & - & - & - \\
\hline 75 & CB $23^{\mathrm{s}}$ & Argentina & - & - & - & - \\
\hline 76 & CB 30 & Brazil & $\ldots$ & + & $\ldots$ & + \\
\hline 77 & CB 32 & Brazil & $\ldots$ & + & $\ldots$ & + \\
\hline 78 & CB 36 & Brazil & $\ldots$ & + & $\ldots$ & + \\
\hline 79 & F1 Hyb. Campines, CB 42u & Brazil & $\ldots$ & + & $\ldots$ & - \\
\hline 80 & F1 Hyb. A. ananassoides $\times$ 'Rondon'u & USA & $\ldots$ & + & $\ldots$ & + \\
\hline 81 & 'Rondon' & Brazil & $\ldots$ & + & $\ldots$ & + \\
\hline 83 & $\mathrm{CB} 61^{\mathrm{t}}$ & Brazil & - & - & - & - \\
\hline 84 & CB $63^{y}$ & Brazil & $\ldots$ & + & $\ldots$ & - \\
\hline 86 & 'Jandaira' & Brazil & $\ldots$ & + & $\begin{array}{l}\cdots \\
\cdots\end{array}$ & - \\
\hline 87 & 'Rezende' & Brazil & $\ldots$ & + & $\ldots$ & - \\
\hline 88 & $\mathrm{CB} 71^{\mathrm{y}}$ & Brazil & $\ldots$ & - & $\ldots$ & - \\
\hline 89 & $\mathrm{CB} 73^{\mathrm{z}}$ & Brazil & $\ldots$ & + & $\ldots$ & - \\
\hline 90 & 'Prazeres' & Brazil & - & - & - & - \\
\hline 91 & Trinidad & Trinidad \& Tobago & $\ldots$ & + & $\ldots$ & - \\
\hline 92 & Cayenne 573 & USA & + & + & + & + \\
\hline 93 & Cayenne 666 & USA & $\ldots$ & + & $\ldots$ & + \\
\hline 94 & Cayenne clone 9 & USA & $\ldots$ & + & $\ldots$ & + \\
\hline 95 & Cayenne 1069 & USA & + & + & - & - \\
\hline 97 & Cayenne 7898 4N & USA & $\ldots$ & + & $\ldots$ & - \\
\hline 98 & Cayenne $45 \# 54 \mathrm{~N}$ & USA & + & + & + & + \\
\hline 99 & Cayenne $314 \mathrm{~N}$ & USA & $\ldots$ & + & $\ldots$ & - \\
\hline 100 & Cayenne $594 \mathrm{~N}$ & USA & - & - & - & + \\
\hline 101 & Cayenne M 4W & USA & $\ldots$ & + & $\ldots$ & + \\
\hline 102 & Cayenne M 24 & USA & $\ldots$ & + & $\ldots$ & - \\
\hline 103 & Cayenne M 61 Low bloom & USA & $\ldots$ & + & $\ldots$ & - \\
\hline 104 & Cayenne M 63 Plus bloom & USA & $\ldots$ & + & $\ldots$ & + \\
\hline 106 & Big eye 'Johnson’s Clone' & USA & $\ldots$ & + & $\ldots$ & + \\
\hline 107 & Cayenne M 105 big eye & USA & $\ldots$ & + & $\ldots$ & + \\
\hline 108 & Cayenne seedy \# 24 & USA & $\ldots$ & + & $\ldots$ & + \\
\hline 109 & Cayenne flowering beauty & USA & + & + & + & + \\
\hline 110 & Cayenne M 109-5 & USA & + & + & + & + \\
\hline 111 & Cayenne M 111 seedy fruit & USA & $\ldots$ & + & $\ldots$ & + \\
\hline 112 & Cayenne paper leaf & USA & $\ldots$ & + & $\ldots$ & - \\
\hline 113 & Cayenne M 262 & USA & + & + & + & + \\
\hline 114 & Cayenne bottleneck & USA & $\ldots$ & + & $\ldots$ & + \\
\hline 115 & Cayenne M 226 nubby & USA & $\ldots$ & + & $\ldots$ & + \\
\hline 116 & Cayenne CPC big eye & USA & $\ldots$ & + & $\ldots$ & - \\
\hline 117 & Cayenne M 35 & USA & $\ldots$ & + & $\ldots$ & - \\
\hline 119 & Cayenne M 267 dry sweet & USA & $\ldots$ & + & $\ldots$ & + \\
\hline 120 & 'Los Banos’ & unknown & - & - & + & + \\
\hline 121 & 'Amarillo' & Brazil & - & - & - & - \\
\hline 122 & ‘Uhi’ & Taiwan & $\ldots$ & + & $\ldots$ & + \\
\hline 123 & 'Red Spanish' & Panama & $\ldots$ & + & $\ldots$ & + \\
\hline 124 & 'Taboga' & Panama & + & + & + & + \\
\hline 125 & Jamaica Sugar' & Jamaica & $\ldots$ & + & $\ldots$ & - \\
\hline 126 & 'Smooth Anpi' & Taiwan & - & - & + & + \\
\hline 127 & ‘Kohi’ & Taiwan & - & - & - & - \\
\hline 128 & 'Spiny Anpi' & Taiwan & - & $\ldots$ & + & + \\
\hline 129 & 'Philippine Green' & Philippines & - & - & + & $\ldots$ \\
\hline 130 & 'Klajatan' & Indonesia & + & + & - & - \\
\hline 131 & 'Ananas Merah' & Indonesia & $\ldots$ & + & $\ldots$ & + \\
\hline 132 & 'Cheese Pine' & Guatemala & $\ldots$ & + & $\ldots$ & - \\
\hline 133 & 'Kew’ & Philippines & $\ldots$ & + & $\ldots$ & - \\
\hline 134 & 'Kumta' & India & $\ldots$ & + & $\ldots$ & - \\
\hline 135 & 'Morada' & Venezuela & $\ldots$ & + & $\ldots$ & + \\
\hline 136 & 'Spanish Criolla Red' & Venezuela & + & + & - & - \\
\hline 138 & 'Red Spanish Pina Lisa' & Venezuela & $\ldots$ & + & $\ldots$ & - \\
\hline 139 & 'Cayenne Azores' & Portugal & $\ldots$ & + & $\ldots$ & + \\
\hline 140 & 'Pakse' & Vietnam & $\ldots$ & + & $\ldots$ & + \\
\hline 141 & 'Do’' & Vietnam & $\ldots$ & + & $\ldots$ & + \\
\hline 142 & 'Den' & Vietnam & + & + & + & + \\
\hline 143 & 'Pina De Castilla' & Columbia & - & - & + & + \\
\hline \multirow[t]{2}{*}{144} & 'Manzana' & unknown & $\ldots$ & + & $\ldots$ & + \\
\hline & & & & & \multicolumn{2}{|c|}{ (continued on next page) } \\
\hline
\end{tabular}


Table 4. (continued from preceding page)

\begin{tabular}{|c|c|c|c|c|c|c|}
\hline \multirow[b]{2}{*}{ No.q } & \multirow[b]{2}{*}{ Name $^{r}$} & \multirow[b]{2}{*}{ Geographic origin } & \multicolumn{2}{|c|}{ PMWaV-1 ${ }^{\circ}$} & \multicolumn{2}{|c|}{ PMWaV-2p } \\
\hline & & & RT-PCR & TBIA & RT-PCR & TBIA \\
\hline 145 & 'Cabezona' & Puerto Rico & $\ldots$ & + & $\ldots$ & - \\
\hline 146 & 'Antigua' & Guatemala & - & - & - & - \\
\hline 147 & Abacaxi Vermelho' & Brazil & $\ldots$ & + & $\ldots$ & + \\
\hline 148 & CB 24 & Paraguay & - & - & - & - \\
\hline 149 & CB 33 & Brazil & - & - & - & - \\
\hline 150 & CB 38 & Brazil & + & + & - & $\ldots$ \\
\hline 151 & CB 46 & Brazil & $\ldots$ & + & $\ldots$ & + \\
\hline 152 & 'Rezende' & Brazil & $\ldots$ & + & $\ldots$ & + \\
\hline 154 & CB 67 & Brazil & $\ldots$ & + & $\ldots$ & + \\
\hline 155 & $\ldots$ & USA & - & - & - & - \\
\hline 156 & $58-696$ & USA & - & - & - & - \\
\hline 157 & $63-759$ & USA & - & - & - & - \\
\hline 158 & $57-503$ & USA & $\ldots$ & - & $\ldots$ & - \\
\hline 159 & $58-1184$ & USA & $\ldots$ & + & $\ldots$ & - \\
\hline 160 & $53-116$ & USA & - & - & - & - \\
\hline 161 & $58-474$ & USA & - & - & - & - \\
\hline 162 & Cayenne John Teves & USA & $\ldots$ & + & $\ldots$ & - \\
\hline 163 & N91-05 & Thailand & $\ldots$ & + & $\ldots$ & - \\
\hline 169 & 32424, N91-17 & USA & $\ldots$ & + & $\ldots$ & - \\
\hline 171 & $\ldots$ & $\ldots$ & $\ldots$ & + & $\ldots$ & - \\
\hline$\ldots$ & Singapore & Malaysia & $\ldots$ & + & $\ldots$ & + \\
\hline
\end{tabular}

significantly higher in areas with mealybugs and MWP, indicating that transmission of PMWaVs occurs in the field. There is no evidence that PMWaV-1 and PMWaV-2 are mechanically transmitted between pineapple plants. Crown materials used for planting new crops are dipped in an insecticide effective against mealybugs prior to being planted. We suggest that eliminating alternate hosts of mealybugs from areas adjacent to pineapple fields and eliminating PMWaV-2-infected pineapple within the field could serve as alternatives for managing MWP.
Identification of PMWaV-infected plants on the massive scale that would be required for converting a plantation over to PMWaV-2-free planting material would be a major financial and technological undertaking. However, small-scale efforts to reduce PMWaV-2-infected plant material in the field could lessen the chances of MWP occurring in the event that mealybugs infestations do occur. One method for reducing PMWaV-2 source plants is to rogue MWP-symptomatic plants and other pineapple plants in the immediate vicinity of symptomatic plants. The distance that
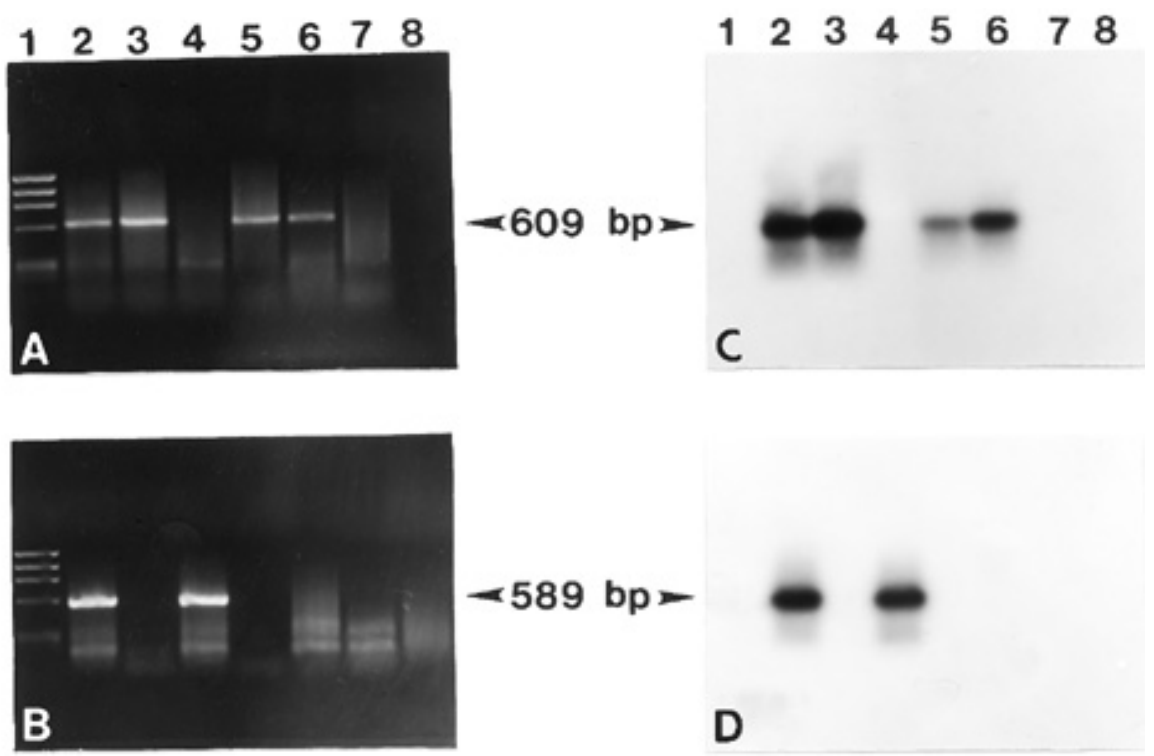

Fig. 2. Detection and differentiation of Pineapple mealybug wilt-associated virus-1 (PMWaV-1) and PMWaV-2 with reverse transcription-polymerase chain reaction (RT-PCR) and Southern analyses. RT-PCR analysis with A, PMWaV-2- and B, PMWaV-1-specific primers. Southern analysis of $\mathbf{C}$, PMWaV-2 and D, PMWaV-1 ampilcons with clones from the HSP 70 homolog genes of the respective viruses. Lane 1, PhiX 174/Hae III digest marker; lane 2, plant infected with both PMWaV-1 and PMWaV-2; lanes 3 and 5, plants infected with PMWaV-2 only; lane 4, plant infected with PMWaV-1 only; lane 6, mealybugs from PMWaV-2-infected plant; lane 7, PMWaV-1- and PMWaV-2-free plant; lane 8, water control. Plant status was confirmed with PMWaV-specific tissue blot immunoassay.

constitutes "immediate vicinity" remains to be established and will likely have to account for mealybug population size, duration of exposure, and initial PMWaV-2 infection rate in the crop. Roguing of MWP-symptomatic plants was a common practice in the Hawaiian pineapple industry until the last few decades, when chemical approaches to mealybug control became routine and the costs of labor increased. It has previously been shown that MWP tends to occur in aggregated patterns (14). We suggest that crowns from plants exhibiting mealybug wilt or plants immediately adjacent to MWP-symptomatic plants should not be used for replanting. Under some conditions, MWP-symptomatic plants can recover and new leaves do not exhibit MWP symptoms (7, D. M. Sether and J. S. Hu, unpublished data), yet the plants and the propagules remain infected with virus. This recovery state necessitates identifying and marking MWP areas while they are apparent so that propagules collected at a later time will not be used for new plantings.

PMWaV-2 infection is much less common than PMWaV-1 infection in Hawaii. MWP-symptomatic plants may simply fail to produce fruit or propagules. Previously, we detected a reduction in the number of fruit produced in the ratoon cycle from PMWaV-infected plants relative to PMWaV-free plants (23). We have repeatedly observed lower PMWaV-2 infection rates in crown propagules from healthy-appearing ratoon crops than from crowns produced on healthy-appearing plant crops. Selection against PMWaV-2infected MWP-symptomatic plants may already be occurring. Crown material is usually harvested simultaneously with the fruit. We have previously shown positive correlations between PMWaV infection and precocious, or premature, fruit matu- 
ration (20). Unless special efforts are made to harvest precocious fruit, these fruit and the accompanying crown can be lost. If MWP plants are fruiting asynchronously with other plants, then crowns from MWP-symptomatic and, concomitantly, PMWaV-2-infected crowns are selected against.

Elimination of PMWaV-1-infection was achieved through apical and lateral bud propagation. Plants derived from infected crowns that were determined to be PMWaV-free following bud propagation remained free of infection after being planted to soil for over 12 months. This method provides a means of recovering PMWaV-free material from infected propagation material. It is especially valuable for pineapple selections which are $100 \%$ infected with at least one PMWaV, such as the Hawaiian proprietary selection number 5 (12), and for the accessions maintained at the USDA-ARS NCGR. Treatment of the crowns with heat prior to excising buds did not ensure that buds were PMWaV free. Rather, trimming the bud to a 1-mm square or smaller appeared to be the critical factor for recovering PMWaV-1-free plants. Similar experiments to eliminate PMWaV2 are in progress.

Table 5. Potential alternate hosts of Pineapple mealybug wilt-associated virus-1 (PMWaV-1) and PMWaV-2 challenged with viruliferous mealybugs ${ }^{\mathrm{w}}$

\begin{tabular}{|c|c|c|c|c|}
\hline Plant & PMWaV-1 & PMWaV-2 & VMB $^{x}$ & Host $^{y}$ \\
\hline Agave sisalana (Engelm.) Perrine (sisal) & $0 / 3$ & $0 / 3$ & $0 / 3$ & + \\
\hline Albizzia lebbeck (L.) Benth. (siris tree) & $0 / 2$ & NT & NT & $\mathrm{U}$ \\
\hline Ananas comosus (L.) Merr. 'Smooth Cayenne' (pineapple) & $10 / 10$ & $5 / 5$ & $3 / 3$ & + \\
\hline Cassia occidentalis $\mathrm{L}$. & $0 / 3^{x}$ & NT & $0 / 3$ & $+1-$ \\
\hline Chenopodium quinoa Willd. (lamb's quarters) & $0 / 3^{x}$ & $0 / 3$ & $0 / 3$ & - \\
\hline Chloris radiata (L.) Swartz (finger grass) & $0 / 15$ & $0 / 10$ & $0 / 5$ & + \\
\hline Citharexylum spinosum (fiddlewood) L. & $0 / 2$ & $0 / 2$ & NT & $\mathrm{U}$ \\
\hline Epipremnum pinnatum (L.) Engl. & $0 / 1$ & NT & NT & $\mathrm{U}$ \\
\hline Eragrostis tenella (L.) Beauv. (Lovegrass) & $0 / 2$ & $0 / 2$ & $0 / 1$ & + \\
\hline Musa domestica 'Grand Nain' (banana) & $0 / 3$ & NT & $0 / 3$ & + \\
\hline M. domestica 'Williams' (banana) & $0 / 3$ & NT & $0 / 3$ & + \\
\hline Nicotiana benthamiana Domin. & $0 / 3^{x}$ & NT & $0 / 3$ & $+/-$ \\
\hline N. clevelandii A. Gray & $0 / 3^{x}$ & NT & $0 / 3$ & $+1-$ \\
\hline N. tobaccum (tobacco) L. & $0 / 3^{x}$ & NT & $0 / 3$ & - \\
\hline Panicum maximum Jacq. (Gui & $0 / 6$ & $0 / 6$ & $0 / 2$ & + \\
\hline Panicum repens L. (Wainaku grass) & $0 / 8$ & $0 / 8$ & $0 / 2$ & + \\
\hline Paspalum sp. & $0 / 2$ & $0 / 2$ & $0 / 2$ & + \\
\hline Psidium cattleianum Sabine (strawberry guava) & $0 / 1$ & NT & NT & $\mathrm{U}$ \\
\hline P. guajava L. (common guava) & $0 / 2$ & NT & NT & $\mathrm{U}$ \\
\hline Saccharum officinarum L. (sugarcane) & $0 / 5$ & $0 / 2$ & NT & $t^{\mathrm{z}}$ \\
\hline Sorghum halepense (L.) Pers. (Johnson & $0 / 5$ & $0 / 5$ & $0 / 2$ & + \\
\hline Trichachne insularis (L.) Nees (Sour grass) & $0 / 3$ & $0 / 3$ & NT & $\mathrm{U}$ \\
\hline
\end{tabular}

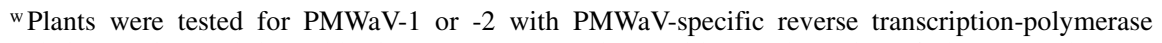
chain reaction and tissue blot immunoassay; number positive/total number of plants tested; NT = not tested.

${ }^{x}$ Plants were inoculated with PMWaV viruliferous mealybugs (VMB).

$\mathrm{y}+=$ mealybug host $;-=$ refractory to mealybug feeding; $+/-=$ mealybugs survived on the plant for 5 days but plant was not a preferred host; $\mathrm{U}=$ unknown.

${ }^{\text {z }}$ Previously identified as a host of Dysmicoccus brevipes (17).

Table 6. Elimination of Pineapple mealybug wilt-associated virus-1 (PMWaV-1) infection through apical and axillary bud propagation

\begin{tabular}{lccccc}
\hline Selection $^{\mathbf{u}}$ & Size $^{\mathbf{v}}$ & 1st treatment $^{\mathbf{w}}$ & 2nd treatment $^{\mathbf{x}}$ & Crowns/buds excised $^{\mathbf{y}}$ & PMWaV-1-free $^{\mathbf{z}}$ \\
\hline 5 & $\mathrm{~S}$ & $35^{\circ} \mathrm{C} / 24 \mathrm{~h}$ & $58^{\circ} \mathrm{C} / 40 \mathrm{~min}$ & $5 / 6$ & $13 / 17(76 \%)$ \\
5 & $\mathrm{M}$ & $35^{\circ} \mathrm{C} / 24 \mathrm{~h}$ & $58^{\circ} \mathrm{C} / 40 \mathrm{~min}$ & $10 / 6$ & $15 / 20(75 \%)$ \\
2 & $\mathrm{~S}$ & $35^{\circ} \mathrm{C} / 24 \mathrm{~h}$ & $56^{\circ} \mathrm{C} / 60 \mathrm{~min}$ & $3 / 12$ & $8 / 8(100 \%)$ \\
2 & $\mathrm{M}$ & $35^{\circ} \mathrm{C} / 24 \mathrm{~h}$ & $56^{\circ} \mathrm{C} / 60 \mathrm{~min}$ & $5 / 12$ & $9 / 10(90 \%)$ \\
2 & $\mathrm{~L}$ & $35^{\circ} \mathrm{C} / 24 \mathrm{~h}$ & $56^{\circ} \mathrm{C} / 60 \mathrm{~min}$ & $2 / 12$ & $13 / 14(93 \%)$ \\
5 & $\mathrm{~S}$ & None & None & $6 / 6$ & $14 / 15(93 \%)$ \\
5 & $\mathrm{M}$ & None & None & $12 / 6$ & $33 / 40(83 \%)$ \\
5 & $\mathrm{~L}$ & None & None & $2 / 6$ & $9 / 9(100 \%)$ \\
2 & $\mathrm{~S}$ & None & None & $1 / 12$ & $6 / 6(100 \%)$ \\
2 & $\mathrm{M}$ & None & None & $2 / 12$ & $9 / 9(100 \%)$ \\
2 & $\mathrm{~L}$ & None & None & $2 / 12$ & $9 / 9(100 \%)$ \\
\hline
\end{tabular}

u Proprietary selection of Ananas comosus 'Smooth Cayenne'.

v Crowns were graded by size: $\mathrm{S}=150$ to $200 \mathrm{~g}, \mathrm{M}=201$ to $250 \mathrm{~g}$, and $\mathrm{L}=251$ to $300 \mathrm{~g}$.

${ }^{\mathrm{w}}$ Crowns were submerged in a water bath at a given temperature/duration of treatment.

${ }^{\mathrm{x}}$ Immediately following first heat treatment, crowns were submerged at a given temperature/duration of treatment.

y Total number of crowns used/total number of excised buds from each crown.

${ }^{\mathrm{z}}$ Total number of PMWaV-free plants based on PMWaV-1-specific reverse transcription-polymerase chain reaction assays and tissue blot immunoassays/total number surviving excision; percentage of PMWaV-1-free plants.

\section{ACKNOWLEDGMENTS}

We thank W. Borth and M. Melzer for providing comments and suggestions regarding this manuscript.

\section{LITERATURE CITED}

1. Borroto, E. G., Cintra, M., Gonzalez. J., Borroto, C., and Oramas, P. 1998. First report of closterovirus-like particle associated with pineapple plants (Ananas comosus cv. Smooth Cayenne) affected with pineapple mealybug wilt in Cuba. Plant Dis. 82:263.

2. Carter, W. 1933. The pineapple mealy bug, Pseudococcus brevipes, and wilt of pineapples. Phytopathology 23:207-242.

3. Carter, W. 1934. Mealybug wilt and green spot in Jamaica and Central America. Phytopathology 24:424-426.

4. Carter, W. 1942. Geographic distribution of mealybug wilt with some other insect pests of pineapple. J. Econ. Entomol. 35:10-15.

5. Carter, W. 1945. Some etiological aspects of mealybug wilt. Phytopathology 35:305-315.

6. Carter, W. 1951. The feeding sequence of Pseudococcus brevipes (Ckl.) in relation to mealybug wilt of pineapples in Hawaii. Phytopathology 41:769-780.

7. Carter, W. 1963. Mealybug wilt of pineapple; a reappraisal. Ann. N. Y. Acad. Sci. 105:741764.

8. German, T. L., Ullman, D. E., and Gunashinghe, U. B. 1992. Mealybug wilt of pineapple. Adv. Dis. Vector Res. 9:241-259.

9. Gunasinghe, U. B., and German, T. L. 1989. Purification and partial characterization of a virus from pineapple. Phytopathology 79:1337-1341.

10. Hu, J. S., Gonsalves, A., Sether, D., and Ullman, D. E. 1993. Detection of pineapple closterovirus, a possible cause of mealybug wilt of pineapple. Acta Hortic. 334:411-416.

11. Hu, J. S., and Sether, D. M. 1999. Etiology of mealybug wilt of pineapple. Page 321 in: Abstr. Xth Int. Congr. Virol. Sydney, Australia.

12. Hu, J. S., Sether, D. M., Liu, X. P., Wang, M., Zee. F., and Ullman, D. 1997. Use of a tissue blotting immunoassay to examine the distribution of pineapple mealybug wiltassociated virus in Hawaii. Plant Dis. 81:1150-1154.

13. Hu, J. S., Sether, D. M., and Ullman, D. E. 1996. Detection of pineapple mealybug wiltassociated virus in pineapple plants and mealybugs using monoclonal antibodies. Plant Pathol. 45:829-836.

14. Hughes, G., and Samita, S. 1998. Analysis of patterns of pineapple mealybug wilt disease in Sri Lanka. Plant Dis. 82:885-890

15. Illingworth, J. F. 1931. Preliminary report on evidence that mealybugs are an important factor in pineapple wilt. J. Econ. Entomol. 24:877-889.

16. Karasev, A. V. 2000. Genetic diversity and evolution of closteroviruses. Annu. Rev. Phytopathol. 38:293-324.

17. McKenzie, H. L. 1967. Mealybugs of California. University of California Press, Berkeley and Los Angeles, CA.

18. Melzer, M. J., Karasev, A. V., Sether, D. M. and $\mathrm{Hu}$, J. S. 2001. Nucleotide sequence, genome organization, and phylogenetic analysis of pineapple mealybug wilt-associated virus2. J. Gen. Virol. 82:1-7.

19. Rohrbach, K. G., Beardsley, J. W., German, T. L., Reimer, N. J., and Sanford, W. G. 1988 Mealybug wilt, mealybugs, and ants on pineapple. Plant Dis. 72:558-565.

20. Sether, D. M., and Hu, J. S. 1998. Corollary analyses of the presence of pineapple mealybug wilt associated virus and the expression of mealybug wilt symptoms, growth reduction, and/or precocious flowering of pineap- 
ple. (Abstr.) Phytopathology 88:S80.

21. Sether, D. M., and Hu J. S. 1999. Mealybugs and pineapple mealybug wilt associated virus are both necessary for mealybug wilt. (Abstr.) Phytopathology 89:S70.

22. Sether, D. M., and Hu, J. S. 2000. A closterovirus and mealybug exposure are both necessary components for mealybug wilt of pineapple symptom induction. (Abstr.) Phyto- pathology 90:S71.

23. Sether, D. M., and Hu, J. S. The impact of pineapple mealybug wilt-associated virus and reduced irrigation on pineapple yield. Australas. Plant Pathol. 30:31-36.

24. Sether, D. M., Ullman, D. E., and Hu, J. S. 1998. Transmission of pineapple mealybug wilt-associated virus by two species of mealybug (Dysmicoccus spp.). Phytopathology
88:1224-1230.

25. Singh, S. J., and Sastry, K. S. M. 1974. Wilt of pineapple-a new virus disease in India. Indian Phytopathol. 27:298-303.

26. Wakman, W., Teakle, D. S., Thomas, J. E., and Dietzgen, R. G. 1995. Presence of a clostero-like virus and a bacilliform virus in pineapple plants in Australia. Aust. J. Agric. Res. 46:947-958. 